Schreyer seems happy to accept at face value Horatio's farewell to the prince as accompanied by flights of angels. The storm in Macbeth, also discussed in the soundscape chapter, leads to an error: the 1584 Chester record concerning a storm relates not to the doomsday play but to the successor to the cycle plays, the Destruction of Jerusalem, and the payment for it was made not to a 'man named Starche' but for starch - presumably to create the effect of rain or snow (142).

Limit such a book to what is provable, however, and it would not be written at all, and scholarship would be the poorer for its absence. Schreyer's large argument about the importance of spectacle, of things on both the pageant wagons and the public stage, and their capacity to transmit significance into a new age, is an important one, as is his plea for a recognition of the value of the past to the Elizabethans, a value made all the more urgent by the Protestant assault on it. Future scholars using his work could usefully check out the primary sources so as to evaluate for themselves the strength of his evidence, but his speculations are always good to think with, and many of them are genuinely illuminating for Shakespeare and the sixteenth-century stage more broadly. The fact that an element of scepticism may remain is no reason for not putting them forward.

\title{
Bart van Es. Shakespeare in Company. Oxford: Oxford University Press, 2013. Pp xiv, 357.
}

TOM RUTTER

Early Theatre 18.1 (2015), 146-8

University of Sheffield

DOI: http://dx.doi.org/10.12745/et.18.1.2336

As Bart van Es notes towards the end of this study, theatre historians over recent decades have uncovered in increasing detail the extent to which Shakespeare as a dramatist was enmeshed in the material conditions of the early modern stage: its finances, its reportorial practices, its networks of patronage, and so on (307-8). Focusing on the institutional parameters that Shakespeare shared with his peers, however, is of no help when it comes to accounting for the differences between him and them. Why is it that Shakespeare, apparently working in the same conditions, produced plays that not only have been more highly acclaimed over the centuries, but that (in van Es's 
view) are qualitatively quite different from those of other playwrights, not least when it comes to 'techniques of characterization' (310)?

The answer offered by this book is that Shakespeare was, in fact, unique in spending most of his career writing for a company in which he was an actor-sharer, in whose playhouse he owned a stake from 1599 onwards, and which enjoyed an unusual level of stability and democracy. In order to make his case, van Es contends that the plays Shakespeare wrote before the establishment of the Lord Chamberlain's Men in 1594 differ from his subsequent work in their lack of stylistic distinctiveness both from the work of other dramatists and between the speeches of different characters. After 1594, though, as a sharer Shakespeare was able to participate in decisions about casting, and hence able to write roles with specific actors in mind. Not only did he thus achieve effects like the visual contrast between the fake-pregnant Doll and the skinny Beadle, presumably played by John Sincler, in 2 Henry $I V, 5.4$ (96), he also developed a form of characterization that depended to an unprecedented extent on relations between characters, as (van Es argues) with the subtle interplay between the mechanicals in A Midsummer Night's Dream (94).

While van Es sensibly resists the temptation to speculate about individual actors' specialisms in the manner of T. W. Baldwin's The Organization and Personnel of the Shakespearean Company (Princeton, 1927), which he mentions in a footnote on 112, he does discuss the possible impact on Shakespeare's writing of two actors about whom we do know somewhat: the clown Robert Armin and the lead actor Richard Burbage. Van Es finds in Armin's published work comic techniques and patterns that Shakespeare may have drawn upon, and while the lack of close verbal parallels makes his case unprovable, the suggestion is thought-provoking. His argument that Hamlet's insistence on the gap between outward show and inward reality depends on Burbage's virtuoso acting is well grounded in a sensitive reading of the play in which that character appears. Indeed, one appealing feature of van Es's book is the way it combines nuanced, thorough, up-to-date theatre history with intelligent criticism of individual plays from Titus Andronicus to The Two Noble Kinsmen. Another is the range of critical approaches that he is able to bring to bear on them, from a stylistically oriented account of the Senecan qualities of Richard III to an exploration of the 'evolving power-dynamics that occur amongst clusters of characters' in Richard II (122). His book is an excellent argument for the way in which a company-oriented approach can synthesize a wide array of methodologies and points of focus. 
Is his overall thesis convincing, though? His hypothesis is certainly very plausible; it makes sense that a dramatist who knew the actors he was writing for, and who was able to develop his scripts in partnership with them, would produce a different sort of play from one who simply sold his work to a company. Van Es's case, however, relies on a series of assumptions that are open to debate. One is his opposition between the post-1594 Shakespeare and the pre-1594 Shakespeare, whom van Es not only assumes to have had no regular attachment to a specific company, but who, he argues, started out as a writer and only later became an actor. ${ }^{1}$ This may well be right, but if it is not, van Es's explanation of Shakespeare's changing dramaturgy in terms of a new company role is weakened. A second plank of van Es's argument is his use of Thomas Heywood. Van Es quite rightly identifies Heywood as Shakespeare's nearest equivalent as a playwright who was also an actor and company sharer (in the Earl of Worcester's Men), and finds some interesting points of similarity between Heywood's 1612 Apology for Actors and Hamlet. Van Es wants to use Heywood as an example of how being a sharer could affect dramatic output, and he does this with an account of $A$ Woman Killed with Kindness (139-40). To support his hypothesis about Shakespeare, though, van Es has to argue that Heywood's inability to maintain the artistic standard he achieved in that play was not because he just wasn't as good a dramatist as Shakespeare, but because his company's fortunes took a downturn in 1612. This requires van Es largely to ignore Heywood's plays of the 1600s such as the two-part If You Know Not Me You Know Nobody - apparently highly successful plays, but not notably Shakespearean in their subtlety of characterization.

Finally, van Es spends a lot more time showing how Shakespeare did achieve 'relational' characterization (109) than how his peers did not. In some ways this is inevitable - how does one prove a negative of such dimensions? - but I did feel that Marlowe's Edward II, in particular, might have deserved more attention than it gets. Van Es writes the play off with the comment that 'neither Edward nor Mortimer can be said to have developing relationships (even with the respective objects of their passion, Gaveston and Isabella)', and supports his point about Mortimer with a remark in a footnote that Mortimer 'expresses no desire for Isabella until the end of the play at 5.2, where his wooing meets instant acceptance' (121): this, surely, is selling Marlowe's play somewhat short.

All these objections, however, reflect the fact that van Es offers provocative, worthwhile arguments that deserve a response. His book is an admirable 
synthesis of existing scholarship, locating Shakespeare firmly within the practices of the company for which he acted and wrote.

\section{Notes}

1 Van Es makes the argument at greater length in 'Johannes fac Totum?: Shakespeare's First Contact with the Acting Companies', Shakespeare Quarterly 61 (2010), 551-77.

Margaret Shewring (ed.). Waterborne Pageants and Festivities in the Renaissance: Essays in Honour of J.R. Mulryne. Aldershot: Ashgate, 2013. Pp xxv, 439.

STEVE MENTZ

Early Theatre 18.1 (2015), 149-50

St John's University

DOI: http://dx.doi.org/10.12745/et.18.1.2587

This dense and detailed collection of case studies provides an authoritative overview of waterborne festivities in Renaissance Europe. The volume is presented as a festschrift for J.R. Mulryne, who directed the research program 'Festivals of the European Renaissance' at Warwick's Centre for the Study of the European Renaissance and whose biography introduces this volume in a two-page head note (ix-x). The twenty-one essays range across different European geographies, with concentrations in France, Italy, and England in the later sixteenth century. Some chapters cover more than one location, but a rough count indicates seven chapters primarily exploring festivals in Italy, six on festivals in England, four on French festivals, and smaller numbers concerning festivals in Spain, Denmark, or other locations.

Margaret Shewring's introduction frames the project as exploring 'the cultural significance of th[e] liquid environment' (1) for Renaissance Europe. She celebrates the diversity of the festivals as a 'testament to the wealth of commentary invited by waterborne events' (1) and suggests that this volume aims to produce a 'coherent overview' designed to stimulate 'further study of this important topic' (7). With equal attention to the engineering feats and cultural meanings of waterborne spectacles, the succeeding chapters provide 